\title{
Vezeték nélküli pacemaker: biztonságosság és múködés a rendelkezésre álló klinikai adatok tükrében
}

\author{
Bári Zsolt', Vámos Máté1, 2, Bógyi Péter', Kiss Róbert Gábor¹, \\ Duray Gábor Zoltán ${ }^{1}$
}

\author{
${ }^{1} \mathrm{MH}$ Egészségügyi Központ, Kardiológiai Osztály, Budapest \\ ${ }^{2}$ University Hospital Frankfurt - Goethe University, Department of Cardiology, Frankfurt am Main \\ Levelezési cím: Dr. Duray Gábor Zoltán PhD, MH EK Kardiológiai Osztály, 1134 Budapest, Róbert Károly krt. 44. \\ E-mail: gduray@yahoo.com
}

A vezeték nélküli „leadless” pacemakerek a hagyományos szívritmus-szabályozó kezeléshez köthető leggyakoribb szövődmények kiküszöbölésének céljából kerültek kifejlesztésre. A beültetés perkután intervenció során femorális vénán keresztüli katéteres eljárással történik a jobb kamrába. A felvezető katéter eltávolítását követően a miniatürizált eszköz teljes egészében a jobb kamra üregében helyezkedik el. Az új technológia az utóbbi években lezárult nagy klinikai vizsgálatok kedvező eredményeit követően a mindennapi gyakorlatban is elérhetővé vált. Használata elsősorban a hagyományos kamrai együregü (VVI és VVIR) pacemaker-beültetés indikációjával bíró betegek körében jön szóba. A kedvezőbb kozmetikai eredmény mellett a vezeték nélküli pacemakerek elterjedésével az évtizedek óta használt transzvénás pacemaker-elektródákhoz, illetve a pacemaker-telepzsebhez köthető szövődmények számának csökkenése várható. Mindkét jelenleg forgalomban lévő vezeték nélküli pacemaker esetén hasonló komplikációs rátával számolhatunk. A készülék rögzítésétől függően különböző lehet a kimozdulás esélye, ezzel szemben a szívfalsérülés és a punkciós nyílás körüli érszövődmények hasonló mértékben fordultak elő. A szövődmények fellépésében a betanulási fázis szerepe nem elhanyagolható, ezért a technológia elterjedésével és fejlődésével a későbbiekben a szövődményarány csökkenése várható. Hosszú távú utánkövetési adatok jelenleg még nem állnak rendelkezésünkre a leadless pacemakerekkel kapcsolatban, a jövőben pedig további randomizált vizsgálatokra is szükség lenne a hagyományos pacemakerekkel történő direkt összehasonlítás és a klinikumban betöltendő szerepük pontosabb meghatározása céljából.

Kulcsszavak: vezeték nélküli intrakardiális pacemaker, transzkatéteres beültetés, jobb kamrai ingerlés

\section{Leadless pacemaker - safety and performance in clinical trials}

Leadless pacemakers were developed to eliminate the most common complications associated with coventional transvenous pacemaker therapy. The device is implanted in the right ventricle by using a femoral percutaneous approach and located totally in the right ventricular cavity after removal of the introducer sheath. The new technology is now available in the everyday practice after the favourable results of large clinical trials completed in the last years. Leadless pacemaker could be primarily utilized in patients with indication for conventional single-chamber right ventricular pacemaker (VVI and VVIR) implantation. Besides the better cosmetic result, decline of the complications related to the pacemaker pocket and the transvenous pacemaker leads used for decades is likely by the spread of leadless pacemakers. Similar complication rates can be expected at both presently manufactured leadless devices. The chance of dislodgement can be different depending on the various fixation mechanisms however the incidence of cardiac perforation and vascular complications was similar in clinical trials. The implanter learning curve for this new procedure is not negligible in the occurrence of complications therefore reduction is expected by the spread and the development of the technology in the future. No long-term outcome data are yet available for leadless pacemakers. Further randomized studies are warranted for direct comparison with conventional pacing systems and to define the proper clinical role.

Keywords: leadless intracardiac pacemaker, catheter delivery, right ventricular pacing 


\section{Bevezetés}

Az 1958-ban végzett első transzvénás endokardiális pacemaker-elektróda beültetése óta (1) a pacemaker-terápia óriási fejlődésen ment keresztül. A 21. század modern eszközei ellenére továbbra is számottevő egyes szövődmények gyakorisága a konvencionális pacemakerek beültetése kapcsán. A posztoperatív első hónapokban nem kívánt eseményekkel a betegek akár 10\%-ánál is számolni kell, amelyek elsősorban a pacemaker-generátorhoz (bőrerózió, telepzseb-haematoma, telepzseb-infekció), valamint a transzvénás pacemaker-elektróda beültetéséhez (légmell, szívperforáció, elektróda kimozdulás) köthetők (2, 3). Hosszabb távon a transzvénás elektródák tünnek a hagyományos szívritmus-szabályozó rendszerek leggyengébb pontjának: sérülhet a burkolatuk, eltörhetnek, csatlakozási problémák léphetnek fel, továbbá tromboembóliás eseményeket okozhatnak, illetve elfertőződhetnek. Mivel a fejlett országokban a betegek várható élettartama tovább emelkedik és egyre több pacemaker kerül beültetésre, ezért valószínű, hogy a hosszabb távon jelentkező szövődmények száma is nőni fog. A hagyományos szívritmus-szabályozó rendszerek Achilles-sarkát képező pacemaker-elektródák leváltásának egyre fokozódó igénye vezetett a vezeték nélküli pacemakerek kifejlesztéséhez. Az új vezeték nélküli technológia valójában már több évtizede létező elképzelés megvalósulása. Spickler és munkatársai kutyákon végzett kísérletek alapján már 1970-ben leírták tapasztalataikat a transzvénás úton történő, vezeték nélküli intrakardiális pacemaker-beültetésről (4), amely a mai eszközök prototípusának tekinthető. Ezt követően azonban több mint 40 évre volt szükség ahhoz, hogy az elektronika és elsősorban az energiatárolás technológiája eljusson a humán beültetésekhez szükséges szintre. Tanulmányunk során részletesen ismertetjük az elektróda nélküli pacemakerek főbb jellemzőit és a nagyobb klinikai vizsgálatok eredményeit, amelyeket számos aspektusból összehasonlítunk a hagyományos pacemakerek korábbi klinikai eredményeivel.

\section{A leadless pacemaker felépítése és múk ko̊dése}

2012-ben elsőként a Nanostim ${ }^{\mathrm{TM}}$ vezeték nélküli pacemaker-rendszer (St. Jude Medical, USA) került bevezetésre, amelyet egy évvel később követett a Micra ${ }^{\mathrm{TM}}$ transzkatéteres pacemaker-rendszere (Medtronic, USA). Jelenleg is ez a két típus van forgalomban és használatuk a hagyományos jobb kamrai együregü VVI és VVIR - pacemaker-beültetés indikációjával bíró betegek körében jön szóba. Mindkét készülék MR kondicionális (Micra ${ }^{\mathrm{TM}} 1,5$ és $3 \mathrm{~T}$, teljes test; Nanostim ${ }^{\mathrm{TM}}$ 1,5 T, teljes test) és képesek a szívfrekvenciát a mozgáshoz adaptálni hőmérséklet alapú érzékelő (Nanostim $^{\mathrm{TM}}$ ), illetve 3 tengelyű akcelerométer (Micra ${ }^{\mathrm{TM}}$ ) segítségével. Az intrakardiális vezeték nélküli pacemakerek esetén a nehézséget az jelenti, hogy a készülék a szíven belül helyezkedik el, ezért a mozgásérzékelőnek el kell tudni különítenie a szív mozgását a fizikai terhelésből adódó mozgástól $(5,6)$. Mindkét típus esetén adekvát ingerküszöb és programozás mellett átlagosan 10-12 év a várható elemélettartam. A NanostimM 2013 októberében kapott CE (Conformité européenne) jelölést és jelenleg az amerikai FDA (Food and Drug Administration) elfogadására vár. A Micra ${ }^{\mathrm{TM}} 2015$ áprilisában

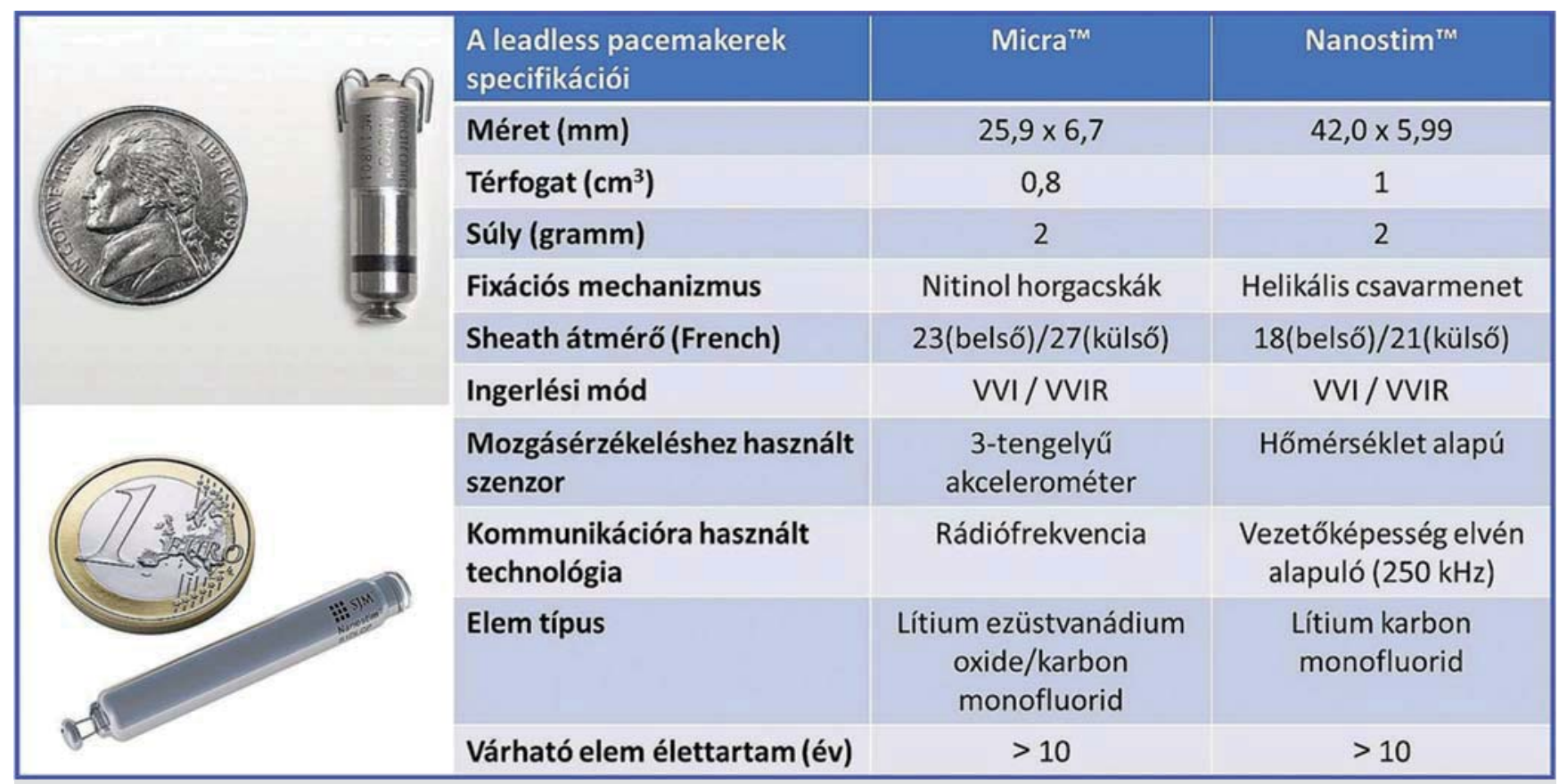

1. ÁBRA. A leadless pacemakerek főbb jellemzői (Fotók forrása: Medtronic, St. Jude Medical) 


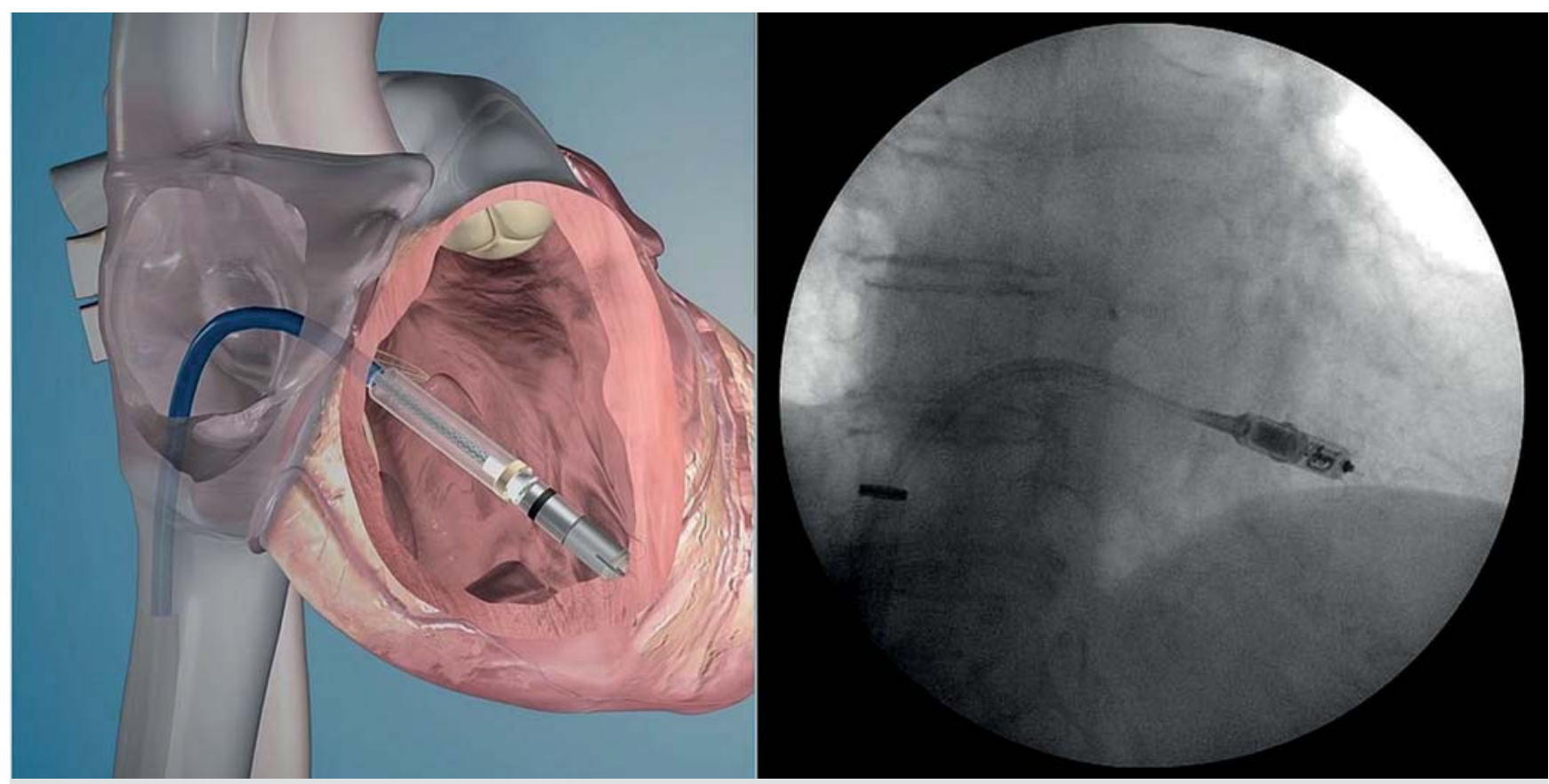

2. ÁBRA. A MicraTM leadless intrakardiális pacemaker transzkatéteres beültetésének sematikus ábrázolása, illetve posteroanterior (PA) mellkas-röntgenfelvétele (bal oldali kép forrása: Medtronic, PA mellkasröntgen saját anyagunkból)

kapott CE-jelölést és rá egy évre, 2016 áprilisában az FDA-engedélyt is megszerezte. A Nanostim ${ }^{\mathrm{TM}} 42 \mathrm{~mm}$ hosszú, míg a Micra'⿳一 25,9 mm, ugyanakkor mindkét készülék közel azonos térfogatú $\left(1 \mathrm{~cm}^{3}\right.$ vs. $\left.0,8 \mathrm{~cm}^{3}\right)$ (1. ábra). A beültetés menete mindkét rendszer esetén hasonló: a kapszulaméretű vezeték nélküli pacemakereket helyi érzéstelenítés mellett, femorális véna punkciót követően katéter segítségével juttatjuk el a jobb kamrába. A munkacsatornául szolgáló bevezető hüvely a Nanostim ${ }^{\mathrm{TM}}$ esetén 18 French $(\mathrm{Fr})$ belső- és $21 \mathrm{Fr}$ ( 7 milliméter) külső átmérővel, míg a Micra ${ }^{\mathrm{TM}}$ esetén 23 Fr belső és 27 Fr (9 milliméter) külső átmérővel bír. $A$ katéter segítségével a jobb kamrában történő pozicionálást követően a készülék a megfelelőnek tűnő helyen kerül implantálásra, amely a Nanostim ${ }^{\mathrm{TM}}$ esetében egy nagy helikális csavarmenet (clockwise tekerés) segítségével történik, míg a Micra ${ }^{\mathrm{TM}}$ esetén 4 apró, hajlékony, elektromosan inaktív, öntáguló nitinol fémhorgocska segít a készülék myocardiumhoz történő rögzítésében. Ezután az általános elektromos paraméterek - ingerküszöb, jelnagyság és impedancia - mérése következik, majd megfelelő értékek esetén nagy felbontású fluoroszkópia mellett enyhe, folyamatos húzással a fixációs mechanizmus stabilitásának tesztelése történik. A kapszula-pacemakerek csak egy sikeres húzás tesztet követően kerülhetnek teljes elengedésre a katéterből (2. ábra). Amennyiben kimozdulás észlelhető, a leadless pacemakerek katéteres úton sikeresen visszahúzhatók és eltávolíthatók. A Nanostim ${ }^{\mathrm{TM}}$ esetében erre a célra dedikált 1 vagy 3 hurokkal ellátott mozgatható katéter áll rendelkezésre, míg a Micra ${ }^{\mathrm{TM}}$ esetén az eszköz megragadása egy hagyományos hajlított hurok és a beültetésre használt „,dokkoló” katéter kombinációjával valósítható meg. A készülékek visszahúzására és biztonságos eltávolítására rövid- és középtávon már rendelkezünk bíztató adatokkal $(7,8)$, azonban sokéves, lemerülő félben lévő eszközökről és azok eltávolításáról egyelőre nincs megbízható klinikai tapasztalatunk. Alternatív megoldásként a leadless pacemaker inaktiválása és az eltávolítás mellőzése is mérlegelhető, mivel a készülék $1 \mathrm{~cm}^{3}$-es mérettel a szívüregnek csupán csekély részét foglalja el.

\section{Klinikai adlatok és evidenciák a biztonságosságról és múkiődésröll}

Az első humán, vezeték nélküli pacemaker-vizsgálat a LEADLESS (NCT 01700244) trial volt, amelyben 33 beteg került bevonásra 3 különböző centrumban 2012 decembere és 2013 áprilisa között (9). 32 betegbe (97\%) ültettek sikeresen Nanostim ${ }^{\mathrm{TM}}$ készüléket és a 90 napos utánkövetési időszak során a betegek 94\%-ánál (31/33) nem tapasztaltak súlyos nem kívánatos eseményt. Major szövődményként egy betegnél szívtamponád fordult elő, amely szívsebészeti beavatkozást igényelt ( 2 héttel később a beteg iszkémiás stroke következtében elhunyt). A fennmaradó 31 betegnél 12 hónap utánkövetés során tartósan megfelelő elektromos paramétereket mértek és pacemakerhez köthető szövődményt nem tapasztaltak (10).

A következő klinikai vizsgálat a LEADLESS II volt (The LEADLESS Pacemaker IDE Study, NCT02030418), amely 3 ország (USA, Kanada, Ausztrália) 56 centru- 
mában zajlott prospektív, nem randomizált módon, a vezeték nélküli pacemaker-rendszer biztonságosságának és hatékonyságának megítélése céljából (11). A vizsgálatba 526 beteg került bevonásra 2014 februárja és 2015 júniusa között (átlagéletkor $75 \pm 8$ év, 62\% férfi). A vizsgálat során $95,8 \%$-os beültetési sikerarányt értek el (504/526), a beavatkozáshoz szükséges átlagos időtartam $28,6 \pm 17,8$ perc volt és a betegek $70 \%$-ánál az elsőként választott pozícióba sikerült beültetni a készüléket. Egyértelműen készülékhez köthető, súlyos, nem kívánatos esemény 34 (6,5\%) betegben fordult elő. Perikardiális folyadékgyülem a betegek 1,5\%-ában jelentkezett, amely 1,1\%-ban igényelt intervenciót. Érszövődmények (vérzés, AV-fisztula, pszeudoaneurizma, a punkciós nyílás sebészi zárása) a betegek 1,2\%-ában, pacemaker-kimozdulás pedig 1,1\%-ban fordult elő. 4 beteg esetén $(0,8 \%)$ a pacemaker eltávolításra került (intervallum 1-413 nap) megemelkedett ingerküszöb miatt. Az átlagos R-hullám nagyság és ingerküszöb tekintetében szignifikáns javulás volt megfigyelhető az első 12 hónapban, míg az impedancia szignifikáns csökkenést mutatott. 2016 októberében a gyártó (St. Jude Medical) figyelmeztetést és átmeneti beültetési tilalmat adott ki a Nanostim ${ }^{\mathrm{TM}}$-re, miután a betegek 0,5\%-ánál (7/1423) elem meghibásodást észleltek 29-37 hónappal az implantációt követően.

Időrendben a harmadik klinikai vizsgálat a Mic$\mathrm{ra}^{\mathrm{TM}}$-val történt (Micra Transcatheter Pacing Study, NCT02004873), amely szintén egy globális, multicentrikus, prospektív, nem randomizált vizsgálat volt a készülék biztonságosságának és hatékonyságának igazolására (12). A vizsgálatba összesen 725 , I. vagy II. osztályú VVIR-pacemaker-beültetés indikációjával bíró beteg (a 2008-as amerikai pacemaker-ajánlás sze-

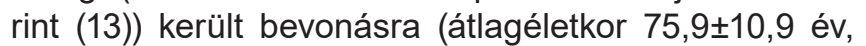
58,8\% férfi) 2013 decembere és 2015 májusa között. A betegek 99,2\%-ában sikeres beültetést végeztek (719/725), a beavatkozáshoz szükséges átlagos időtartam 23,0 $\pm 15,3$ perc volt. Egyértelműen készülékhez köthető major szövődmény 25 betegben $(3,4 \%)$ fordult elő: szívperforáció 1,6\%-ban (csak az első 6 hónap analízise mutatott 1,6\%-ot, viszont a későbbiekben a teljes vizsgálatban $1,52 \%$ volt a perforáció előfordulása, perikardiocentézis 1,0\%-ban, szívsebészeti beavatkozás 0,3\%-ban történt), érszövődmények (AV-fisztula, pszeudoaneurizma) 0,7\%-ban, vénás tromboembóliás események 0,3\%-ban, megemelkedett ingerküszöb a betegek 0,3\%-ában jelentkezett. Pacemaker-diszlokáció nem történt és az elektromos paraméterek is sta- bilak maradtak az első 6 hónapnyi utánkövetés során (1. táblázat). A Magyar Honvédség Egészségügyi Központjában 2014 februárjában a világon harmadikként ültethettünk be Micra ${ }^{\mathrm{TM}}$ vezeték nélküli pacemakert a klinikai vizsgálat keretein belül és a későbbiekben a legtöbb implantációt végző vizsgálói centrumnak is intézményünk bizonyult. Duray Gábor és munkatársai a Micra $^{\text {TM }}$ klinikai vizsgálaton belül részletesen vizsgálták hosszabb távon is a rendszer biztonságosságát és müködését (14), amely során a kedvező primer eredmények megerősítést nyertek. 1 éves utánkövetés alatt a betegek 96\%-ánál nem fordult elő major szövődmény. Az első 24 hónapban a jobb kamrai ingerküszöb alacsony és stabil maradt, valamint az implantációtól számítva a becsült várható elemélettartam 12,1 év volt. Post hoc analízist folytatva, az új vezeték nélküli pacemaker biztonságosságát és működését a ,,hagyományos" pacemakerrel is összehasonlították, felhasználva ehhez 2667 beteg adatát 6 korábbi, Medtronic által szponzorált kétüregű pacemakerekkel történt vizsgálatból. Az analízishez a jobb pitvari elektródához köthető nem kívánatos eseményeket kizárták és propensity score matching módszerrel párosítást végeztek. A vizsgálat igazolta, hogy a Micra ${ }^{\mathrm{TM}}$ beültetésen átesett betegeknél a major szövődmények rizikója 48\%-kal alacsonyabb volt (HR: 0,52; 95\% Cl: 0,35-0,77; $p=0,001$ ) a klasszikus transzvénás csoporthoz képest az implantációt követő első 12 hónapban. Az rizikócsökkenés elsősorban a hospitalizációban bekövetkező 47\%-os relatív rizikócsökkenés és a pacemaker-revíziók 82\%-os relatív rizikócsökkenésének volt köszönhető. A major szövődmények alacsonyabb rizikója a Micra ${ }^{\mathrm{TM}}$ betegek valamennyi alcsoportjában (életkor, nem, társbetegségek szerinti csoportok) megfigyelhető volt.

A jelenleg is zajló Micra ${ }^{\mathrm{TM}}$ „post market” regiszter előzetes adatai valós, mindennapi körülmények mellett is megerősítették a Micra ${ }^{\mathrm{TM}}$ vizsgálat kedvező eredményeit; az implantációt követő 30 napon belül a major szövődményarány 1,51\%-nak bizonyult, de perikardiális folyadék, illetve perforáció csak 0,13\%-ban fordult elő (15).

A Nanostim ${ }^{\mathrm{TM}}$ esetén is bizonyítást nyert a leadless pacemakerek konvencionális VVI pacemakerekkel szembeni kedvezőbb szövődmény aránya a beültetést követő első 12 hónapban. A vizsgálat során a két kohorsz 718 leadless pacemakerrel rendelkező és 10521 transzvénás VVI-pacemakerrel bíró betegből állt (USA, Truven MarketScan). Egy hónapon belül a leadless csoportban a betegek 5,8\%-ában észleltek szövőd-

\begin{tabular}{|c|c|c|c|c|c|}
\hline $\begin{array}{l}\text { Leadless intrakar- } \\
\text { diális pacemakerek }\end{array}$ & $\begin{array}{l}\text { Betegszám } \\
\text { (db) }\end{array}$ & $\begin{array}{l}\text { Sikeres beül- } \\
\text { tetések (\%) }\end{array}$ & $\begin{array}{l}\text { Major szövőd- } \\
\text { mények (\%) }\end{array}$ & $\begin{array}{l}\text { Perforáció/perikar- } \\
\text { diális effúzió (\%) }\end{array}$ & $\begin{array}{l}\text { Készülék } \\
\text { kimozdulás (\%) }\end{array}$ \\
\hline Nanostim $^{\mathrm{TM}}$ & 526 & 95,8 & 6,5 & 1,5 & 1,1 \\
\hline Micra $^{\mathrm{TM}}$ & 725 & 99,2 & 3,4 & $1,6^{*}$ & 0 \\
\hline
\end{tabular}

*A Micra ${ }^{T M}$ vizsgálatban a teljes populációra nézve 1,52\% volt a perforáció/perikardiális effúzió előfordulása és csak az első 6 hónap analízise mutatott 1,6\%-ot! 
ményt (készülékkimozdulás 1,0\%; perikardiális effúzió $1,5 \%$ stb.), míg a hagyományos pacemaker-csoportban 12,7\%-ban (elektródához köthető nem kívánatos esemény 7,6\%; infekció 1,9\% stb.). Egy hónap után, középtávon a leadless csoportban csupán 0,6\%, míg a hagyományos pacemaker-csoportban $5,4 \%$ volt a szövődmények aránya (16).

A két nagy leadless klinikai vizsgálat szövődmény rátájának összehasonlítását nehezíti az elsődleges biztonságossági végpontok vizsgálatonként eltérő definiálása. A LEADLESS II során észlelt 6,5\%-os készülékhez köthető súlyos, nem kívánt esemény arány a Micra-vizsgálat major szövődményekre vonatkozó kritériumrendszerét használva 4,9\%-ra módosul. Perikardiális effúzió mindkét vizsgálatban a betegek közel 1,5\%-át érintette, azonban készülékkimozdulás csak a Nanostim ${ }^{\mathrm{TM}}$ beültetések kapcsán fordult elő $(1,1 \%)$, amelynek részben oka lehet az eltérő hatékonyságú rögzítő mechanizmus használata. Szívperforációra hajlamosító betegtényezők lehetnek a Micra-vizsgálat adatai szerint a magasabb életkor, a női nem, az alacsony testsúly és a krónikus tüdőbetegség, míg az operatőr részéről a betanulási fázist nevezte meg a Leadless II vizsgálat a készülékhez köthető súlyos, nem kívánatos események egyértelmű rizikófaktorának.

Összességében megállapítható, hogy mind a biztonságosság és a stabil müködés tekintetében hasonlóan jó eredmények születtek a két vezeték nélküli pacemaker-rendszer nagy vizsgálatai során. Indirekt összehasonlítások alapján a transzvénás együregű pacemakerekhez képest az újfajta eszközök azonos hatékonyság mellett rövid- és középtávon biztonságosabbnak tủnnek. A LEADLESS II-ben és a Micra-vizsgálatban a klasszikus pacemaker-implantációhoz köthető szövődmények, mint például a légmell, telepzseb- vagy elektróda-infekció egyáltalán nem fordultak elö, de helyettük femorális véna punkcióból fakadó érszövődmények jelentkeztek, valamint a szívperforáció gyakoribbá vált és súlyosabb következményei voltak. Ezen „újfajta" szövődmények előfordulása között nem volt érdemi különbség a két leadless pacemaker alkalmazása során. Nagyobb felmérések és vizsgálatok adatai szerint a szívperforáció gyakorisága hagyományos, transzvénás eszközök esetén $0,4 \%-0,8 \%(2,3)$. A klasszikus és leadless pacemaker-beültetések során előforduló szívperforáció összehasonlítására Vámos Máté és munkatársai 28 klinikai vizsgálatból származó 60744 fős betegpopuláción végzett metaanalízise a klasszikus pacemaker-beültetésekhez köthetően, átlagosan 0,82\%-os szívperforáció gyakoriságot igazolt a leadless vizsgálatok során tapasztalt 1,5\%-hoz képest (17). A leadless készülékek esetén dokumentált magasabb perforációs ráta hátterében a nagyobb intrakardiális pacemaker-átmérő - a hagyományos pacemaker-elektródákhoz viszonyítva -, a beültetéshez használt katéter relatív vastagsága, az új technológiához köthető betanulási fázis, valamint a klasszikus pacemaker-beülte- tések kapcsán feltételezhetően előforduló több tünetmentes, nem dokumentált eset állhat. A technológia fejlődésével és a betanulási fázis csökkenésével várhatóan ez az arány javulni fog, amelyet már a jelenleg is zajló Micra „post market” regiszterben tapasztalt $0,13 \%$-os perforációs ráta is előre vetít.

\section{A leadless pacemaker potenciális helye aktuálisan a klinikumban és a jo̊vő lehetőségei}

2016-ban Magyarországon 2278 primer együregű kamrai pacemaker-beültetés történt $\mathrm{VVI}(\mathrm{R})$ indikációval. Elméletileg évente körülbelül ennyi beteg részesülhetne leadless pacemaker-beültetésben, azonban ez a szám a jelen magyarországi körülmények, biztosítási feltételek és készülék árak mellett nem realitás. A limitált beültetési lehetőségek miatt csak válogatott esetekben javasolt az újfajta technológia használata, egyénenként történő gondos mérlegelést követően. Leadless pacemaker beültetése megfontolandó, ha a hagyományos transzvénás pacemaker beültetése jelentős rizikóval bír vagy nem jön szóba, mint például az anamnézisben szereplő gyakori elektróda/telepzseb-szövődmények, szívbelhártya-gyulladás (az említett leadless vizsgálatokban infektív endocarditis egyáltalán nem fordult elő), illetve ismert vénás szükület vagy elzáródás (véna subclavia, véna cava superior) eseteiben. Elektróda nélküli pacemaker beültetése mérlegelendő abban az esetben is, ha a betegben tartós intravénás katéter található vagy krónikus veseelégtelenség miatt a beteg rendszeres hemodialízisre szorul. Ezen betegekben egy hagyományos, transzvénás pacemaker-rendszer beültetése esetén fokozott fertőzésrizikóval számolhatunk és hosszabb távon a mindkét oldali vena subclavia „megtartása” is fontos szempont lehet. A leadless pacemakerek magas fertőzéskockázat melletti alkalmazhatóságáról egy centrum kedvező tapasztalatokról számolt be $(18,19)$.

Az intrakardiális pacemakerekkel kapcsolatban továbbra sem tisztázott kérdés, hogy az elem kimerülésének közeledtével mi a megfelelő stratégia. Az erre vonatkozó hosszú távú adatok jelenleg még nem állnak rendelkezésünkre. Az extrakció lehetősége rutinszerüen valószínűtlen megoldás a leadless pacemakerek hoszszabb távon várható, közel teljes endotelizációja miatt (20-23). Kísérleti adatok inkább a lemerült eszközök szívben hagyását és kikapcsolását vetítik előre, mivel a kistérfogatú pacemakerek a jobb kamra működésére nagy valószínüséggel nincsenek káros hatással és akár egy újabb leadless pacemaker is implantálható a szívüregbe kedvezőtlen hemodinamikai hatás nélkül (24).

A vezeték nélküli pacemakerekkel elért kedvező eredmények és az új technológia előnyei miatt jelenleg további kutatások és fejlesztések zajlanak. Ezek egyrészt 
a nagy klinikai vizsgálatokban tapasztalt szövődmények csökkentésére irányulnak az implantációhoz szükséges eszközök további fejlesztésével, másrészt a leadless technológia szélesebb körben történő elterjesztését célozzák. Kettő-, illetve háromüregü vezeték nélküli pacemaker-rendszerekkel már zajlanak klinikai vizsgálatok és a közeljövőben a leadless technológia szubkután defibrillátorral való kombinációja is várható az antitachycardia ingerlés megvalósíthatósága céljából (25).

\section{Következtetések}

A leadless pacemaker a hagyományos szívritmus-szabályozó kezeléshez köthető leggyakoribb szövődmények kiküszöbölése céljából került kifejlesztésre. Az első nagy klinikai vizsgálatok a biztonságosság és a működés tekintetében mindkét vezeték nélküli rendszer esetén hasonlóan kedvező eredményekkel zárultak. A vezeték nélküli pacemakerek elterjedésével az évtizedek óta használt transzvénás pacemaker-elektródákhoz, illetve a pacemaker-telepzsebhez köthető szövődmények számának jelentős csökkenése várható. $A$ klasszikus, transzvénás pacemakerekkel történő direkt összehasonlítás és a klinikumban betöltendő szerepük pontosabb meghatározása céljából a jövőben randomizált vizsgálatok elvégzése szükséges.

\section{Irodalom}

1. Furman S, Schwedel JB. An intracardiac pacemaker for Stokes-Adams seizures. N Engl J Med 1959 Nov 5; 261: 943-8. 10.1056/NEJM195911052611904

2. Udo EO, Zuithoff NP, van Hemel NM, et al. Incidence and predictors of short and long-term complications in pacemaker therapy: the FOLLOWPACE study. Heart Rhythm 2012; 9: 728-35. 10.1016/j. hrthm.2011.12.014

3. Kirkfeldt RE, Johansen JB, Nohr EA, et al. Complications after cardiac implantable electronic device implantations: an analysis of a complete, nationwide cohort in Denmark. Eur Heart J 2014; 35: 1186-94. 10.1093/eurheartj/eht511

4. Spickler JW, Rasor NS, Kezdi P, et al. Totally selfcontained intracardiac pacemaker. J Electrocardiol 1970; 3: 325-31. 10.1016/ S0022-0736(70)80059-0

5. Lloyd M, Reynolds D, Sheldon T, et al. Rate adaptive pacing in an intracardiac pacemaker. Heart Rhythm. 2017 Feb; 14(2): 200-205. 10.1016/j.hrthm.2016.11.016

6. Duray G, Bari Z, Sztaniszlav A, et al. Exercise detection with 3-axis accelerometer of a total intracardiac leadless pacemaker. Oral Presentation, European Society of Cardiology Congress, London, September 1, London; 2015.

7. Reddy VY, Miller MA, Knops RE, et al. Retrieval of the leadless cardiac pacemaker: A multicenter experience. Circ Arrhythm Electrophysiol 2016; 9:e004626. 10.1161/CIRCEP.116.004626

8. Bonner MD, Neafus N, Byrd CL, et al. Extraction of the Micra Transcatheter Pacemaker System. Heart Rhythm 2014; 11: S342 9. Reddy VY, Knops RE, Sperzel J, et al. Permanent leadless cardiac pacing: results of the LEADLESS trial. Circulation 2014; 129 : 1466-1471. 10.1161/CIRCULATIONAHA.113.006987
10. Knops RE, Tjong FV, Neuzil P, et al. Chronic performance of a leadless cardiac pacemaker: 1-year follow-up of the LEADLESS trial. J Am Coll Cardiol 2015; 65: 1497-504. 10.1016/j.jacc.2015.02.022 11. Reddy VY, Exner DV, Cantillon DJ, et al. Percutaneous implantation of an entirely intracardiac leadless pacemaker. N Engl J Med 2015; 373: 1125-35. 10.1056/NEJMoa1507192

12. Reynolds D, Duray GZ, Omar R, et al. A leadless intracardiac transcatheter pacing system. N Engl J Med 2016; 374: 533-541. 10.1056/NEJMoa1511643

13. Epstein AE, DiMarco JP, Ellenbogen KA, et al. ACC/AHA/HRS 2008 guidelines for device-based therapy of cardiac rhythm abnormalities: a report of the American College of Cardiology/American Heart Association Task Force on Practice Guidelines (Writing Committee to Revise the ACC/AHA/NASPE 2002 Guideline Update for Implantation of Cardiac Pacemakers and Antiarrhythmia Devices) developed in collaboration with the American Association for Thoracic Surgery and Society of Thoracic Surgeons. J Am Coll Cardiol 2008; 51(21): e1-62. 10.1016/j.jacc.2008.02.032

14. Duray GZ, Ritter P, El-Chami M, et al. Long-term performance of a transcatheter pacing system: 12-Month results from the Micra Transcatheter Pacing Study. Heart Rhythm 2017 May;14(5):702-709. 10.1016/j.hrthm.2017.01.035

15. Roberts PR, Clementy N, Al Samadi F, et al. A leadless pacemaker in the real-world setting: The Micra Transcatheter Pacing System Post-Approval Registry. Heart Rhythm 2017 May 11. pii: S15475271(17)30595-7. 10.1016/j.hrthm.2017.05.017

16. Reddy VY, Cantillon DJ, Exner DV, et al. A Comparative Study of Acute and Mid-Term Complications of Leadless vs Transvenous Pacemakers. Abstract presented at Heart Rhythm Society Annual Meeting 2016 as LBCT02-04, SanFrancisco, CA, USA.

17. Vamos M, Erath JW, Benz AP, Bari Z, Duray GZ, Hohnloser SH. Incidence of Cardiac Perforation With Conventional and With Leadless Pacemaker Systems: A Systematic Review and Meta-Analysis. J Cardiovasc Electrophysiol 2017 Mar; 28(3): 336-346. 10.1111/ jce. 13140

18. Kypta A, Blessberger H, Lichtenauer M, Steinwender C. Temporary leadless pacing in a patient with severe device infection. BMJ Case Rep 2016 May 17; 2016. 10.1136/bcr-2016-215724.

19. Kypta A, Blessberger H, Kammler J, et al. Leadless Cardiac Pacemaker Implantation After Lead Extraction in Patients With Severe Device Infection. J Cardiovasc Electrophysiol 2016 Sep;27(9):1067-71. 10.1111/jce.13030

20. Vamos M, Honold J, Duray GZ, Hohnloser SH. MICRA Leadless Pacemaker on Autopsy. JACC: Clinical Electrophysiology 2016. 2(5): p. 636-637. 10.1016/j.jacep.2016.02.014

21. Kypta A, Blessberger H, Kammler J, et al. First autopsy description of changes 1 year after implantation of a leadless cardiac pacemaker: unexpected ingrowth and severe chronic inflammation. Can J Cardiol 2016; 32: 1578.e1-1578.e2. 10.1016/j.cjca.2015.12.028

22. Tjong FV, Stam OC, van der Wal AC, et al. Postmortem histopathological examination of a leadless pacemaker shows partial encapsulation after 19 months. Circ Arrhythm Electrophysiol 2015; 8: 1293-1295. 10.1161/CIRCEP.115.003101

23. Borgquist R, Ljungström E, Koul B, Höijer CJ. Leadless Medtronic Micra pacemaker almost completely endothelialized already after 4 months: first clinical experience from an explanted heart. Eur Heart J 2016 Aug; 37(31): 2503. 10.1093/eurheartj/ehw137.

24. Omdahl P, Eggen MD, Bonner MD, et al. Right ventricular anatomy can accommodate multiple micra transcatheter pacemakers. Pacing Clin Electrophysiol 2016; 39: 393-397. 10.1111/pace.12804 25. Tjong FV, Brouwer TF, Smeding L, et al. Combined leadless pacemaker and subcutaneous implantable defibrillator therapy: feasibility, safety, and performance. Europace 2016; 18: 1740-1747. 10.1093/europace/euv457 